\title{
Effects of rare-earth fertilizers on the emission of nitrous oxide from agricultural soils in China
}

\author{
Zhangwei Wang, Xiaoshan Zhang*, Yujing Mu \\ Research Center for Eco-Environmental Sciences, Chinese Academy of Sciences, Beijing 100085, China
}

Received 22 July 2007; received in revised form 10 January 2008; accepted 10 January 2008

\begin{abstract}
Rare-earth fertilizers have long been used in agriculture in China. The consequences of these applications are of more recent concern. In our study, an experiment was carried out to identify the effects of applying rare-earth fertilizers on emission of nitrous oxide from paddy and dryland soils in northern China. Normal dosage of rare-earth fertilizers only, normal dosage of urea only, normal dosage of urea plus rare-earth fertilizers, and a normal urea application plus a 10-fold increase in the dosage of rare-earth fertilizers were applied to the soils in pots, prepared for our experiment. A static closedchamber technique was used to measure nitrous oxide emission flux from the soil in the pots before and after fertilization during the experiment. The results show that the application of only rare-earth fertilizers did not have any visible effect on the emission of nitrous oxide from both paddy and dryland soils. Applying a normal dosage rare-earth fertilizers plus urea led to greater emission of nitrous oxide from the soils than only applying the normal dosage of urea. When a 10-fold increase of rare-earth fertilizers dosage was added to a normal dosage of urea, the emission of nitrous oxide from the soils increased even further. We speculate that the application of rare-earth fertilizers leads to an increase of available $\mathrm{NH}_{4}^{+}-\mathrm{N}$ from urea hydrolysis and activate bacteria and enzymes in nitrification and de-nitrification.
\end{abstract}

(C) 2008 Elsevier Ltd. All rights reserved.

Keywords: Rare-earth fertilizer; Nitrous oxide emission; Agricultural soils

\section{Introduction}

Nitrous oxide $\left(\mathrm{N}_{2} \mathrm{O}\right)$ is a greenhouse gas (Wang and Sze, 1980) and involved in the destruction of stratospheric ozone (Crutzen, 1970). Long-term global measurements of atmospheric $\mathrm{N}_{2} \mathrm{O}$ show an annual growth rate of $0.3 \%$. During the $1990 \mathrm{~s}$, the concentration of $\mathrm{N}_{2} \mathrm{O}$ was about $311 \mathrm{ppbv}$ in the atmosphere (Bouwman, 1990; Battle et al., 1996). Agricultural soils are significant sources of $\mathrm{N}_{2} \mathrm{O}$ (Iserman, 1994; Harrison et al., 1995). The emission

*Corresponding author. Tel./fax: + 861062849369 .

E-mail address: zhangxsh@rcees.ac.cn (X. Zhang). of $\mathrm{N}_{2} \mathrm{O}$ from the application of nitrogen fertilizer to agricultural soils is currently estimated to be 2-3 $\mathrm{Tg} \mathrm{yr}^{-1} \mathrm{~N}_{2} \mathrm{O}-\mathrm{N}\left(1 \mathrm{Tg}=10^{12} \mathrm{~g}\right)$, which accounts for about $21-46 \%$ of total emission from global anthropogenic sources (FAO and IAEA, 1992). Therefore, the emission of $\mathrm{N}_{2} \mathrm{O}$ from agricultural soils has generated considerable attention.

Rare-earth elements (REEs) are members of Group IIIA in the periodic table and all have similar physical and chemical properties. Fertilizers containing REEs (REE fertilizers) have been applied as microelement fertilizers in agriculture since the 1980s. Subsequently, physiological effects of REE fertilizers have been reported in such 
instances as the improvement of membrane stabilization and hormone effectiveness, growth response to coleoptile segments, better nitrogen fixation efficiency and reduction in water loss by plants (Guo, 1998; Brown et al., 1990). Currently, compound fertilizers such as urea, organic compounds and carbon ammonium mixed with REEs are widely used by Chinese farmers (Guo, 1998; Huo and Xiao, 1998). It is estimated that application of REE fertilizers in China covered approximately $3.7 \times 10^{6} \mathrm{hm}^{2}$ in 1993 and $1.6-2.0 \times 10^{7} \mathrm{hm}^{2}$ in 1995 (Peng and Wang, 1995). Other studies also pointed out that exterior rare earth has an effect on the activities of microbes and enzymes and therefore affected nitrogen transformation in soils (Chu et al., 2000a, 2001; Xu and Wang, 2001; Ozaki et al., 2006). $\mathrm{N}_{2} \mathrm{O}$ is primarily emitted into the atmosphere as a result of microbiological activities through the nitrogen cycle in soils (Bouwman, 1990). Consequently, the application of REE fertilizers to agricultural soils might also affect the process of $\mathrm{N}_{2} \mathrm{O}$ generation and further increases the uncertainty of emission estimates of $\mathrm{N}_{2} \mathrm{O}$ from agricultural soils. In this study we carried out an experiment to test the effect of applying rare-earth fertilizers on $\mathrm{N}_{2} \mathrm{O}$ emission from agricultural soils in northern China.

\section{Materials and methods}

\subsection{Soil and REE fertilizers}

Two types of agricultural soil from the north of Beijing $\left(39^{\circ} 60^{\prime} \mathrm{N}, 116^{\circ} 30^{\prime} \mathrm{E}\right)$ were used in this experiment. On one of these soils rice had been cultivated for more than 20 years (hereafter called paddy soil) and on the other wheat had been grown for about 15 years (hereafter called dryland soil). Both soils are typically luvic cinnamon soils found in the temperate monsoon climate of the region. Soil from the first $20 \mathrm{~cm}$ of the surface layer was collected. The basic characteristics of soils were analyzed according to the methods described by
Kim (1995) and are presented in Table 1. The REE fertilizers used in this study was supplied by the Research Center for Agriculture Application of Rare Earth Elements in China. The concentration of REE fertilizers is $212.4 \mathrm{mg} \mathrm{L}^{-1}$, identified as a rare-earth oxide. Individual rare-earth oxide components, as percentages, are listed in Table 2.

\subsection{Experiment}

Both types of soils that we had collected were thoroughly mixed and then $20 \mathrm{~kg}$ (fresh weight) soil was placed in pots for treatment. Five treatments were prepared for both paddy and dryland soils. All treatment soils were stabilized for 2 weeks before REE fertilizers and urea were applied. According to the information from the Research Center for Agriculture Application of Rare Earth Elements in China, the recommended dosage of REE fertilizers for agricultural soil ranged between 0.7 and $3.6 \mathrm{~kg} \mathrm{~h} \mathrm{~m}^{-2}$. In our study the normal dosage of $1.35 \mathrm{~kg}$ REE fertilizers per $\mathrm{hm}^{2}$, corresponding to $0.6 \mathrm{mg}$ REE fertilizers per $\mathrm{kg}$ experimental soil $\left(0.6 \mathrm{mg}_{\mathrm{RE}} \mathrm{kg}^{-1}\right)$, was used. We also applied a 10 fold dosage of REE fertilizers $\left(6.0 \mathrm{mg}_{\mathrm{RE}} \mathrm{kg}^{-1}\right)$ to investigate the consequences of excessive application of REE fertilizers. The application dosage of urea was $0.15 \mathrm{~g}$ per $\mathrm{kg}$ of soil $\left(0.15 \mathrm{~g}_{\text {urea }} \mathrm{kg}^{-1}\right)$ following the recommendation of the fertilization manual (Pang, 1994), which corresponds to $3.0 \mathrm{~g}$ urea per treatment.

A pre-treatment test was conducted to investigate the intrinsic difference in experimental pots of $\mathrm{N}_{2} \mathrm{O}$ emission from the paddy soil and dryland soil. Each treatment applied $3 \mathrm{~g}$ urea, and five replicates were set for each of the soils.

Table 2

Components of REE fertilizers

\begin{tabular}{lllllll}
\hline Component & $\mathrm{La}_{2} \mathrm{O}_{3}$ & $\mathrm{CeO}_{2}$ & $\mathrm{Pr}_{6} \mathrm{O}_{11}$ & $\mathrm{Nd}_{2} \mathrm{O}_{3}$ & $\mathrm{Sm}_{2} \mathrm{O}_{3}$ & Others \\
\hline Percentage & 28.0 & 50.8 & 5.2 & 15.8 & 0.1 & $<0.1$ \\
\hline
\end{tabular}

Table 1

Characteristics of experimental soils

\begin{tabular}{lllll}
\hline Soil & Total $\mathrm{N}\left(\mathrm{g} \mathrm{kg}^{-1}\right)$ & Total $\mathrm{P}\left(\mathrm{g} \mathrm{kg}^{-1}\right)$ & Organic matter $\left(\mathrm{g} \mathrm{kg}^{-1}\right)$ & $\mathrm{pH}_{\left(\mathrm{soil:} \mathrm{H}_{2} \mathrm{O}=1: 5\right)}$ \\
\hline Paddy soil & 11.1 & 5.6 & 21.3 & 7.40 \\
Dryland soil & 9.8 & 8.6 & 14.5 & 7.25 \\
\hline
\end{tabular}


The detailed treatments in the experiment are listed in Table 3. The treatments included the normal dosage of only rare-earth fertilizer, a normal dosage of only urea, a normal dosage of urea plus rare-earth fertilizer, urea plus the 10 -fold dosage of rare-earth fertilizer and a control without any fertilizer application.

Two successive fertilizations were carried out on 13 May 2003 (the first fertilization) and 27 May 2003 (the second fertilization) for the paddy soil and on 9 June 2002 (the first fertilization) and 18 June 2003 (the second fertilization) for the dryland soil. It is to be noted that the $0.6 \mathrm{mg}_{\mathrm{RE}} \mathrm{kg}^{-1}$ dosage was applied in the first fertilization and the $6.0 \mathrm{mg}_{\mathrm{RE}} \mathrm{kg}^{-1}$ dosage in the second fertilization only for the REE fertilizers treatment applications. Both the REE fertilizers and urea were dissolved in distilled water and then applied to the soils, bringing the soil moisture content to about $35 \%$ (W/W).

\subsection{Sample collection and measurement}

A static closed-chamber technique was used to investigate $\mathrm{N}_{2} \mathrm{O}$ flux. The closed-chambers, with radius of $13.5 \mathrm{~cm}$ and height of $60 \mathrm{~cm}$, made of polyvinyl chloride, were placed on each pot used in the experiment and sealed with water. The concentrations of $\mathrm{N}_{2} \mathrm{O}$ in the closed-chamber were linearly correlated $(r=0.998)$ with time over an $80 \mathrm{~min}$ period. Four samples, at intervals $15 \mathrm{~min}$ each, were collected by using a $50 \mathrm{~mL}$ glass syringe from enclosed interspaces. The pressure changes (the four samples accounted for only $0.5 \%$ of the total volume of each chamber) caused by sampling were negligible. Temperature and atmospheric pressure were recorded simultaneously.

A gas chromatograph (Hewlett Packard 5890), fitted with a $4 \mathrm{~mm} \times 3 \mathrm{~m}$ stainless steel column packed with Porapack Q (80-100 mesh) and an electron capture detector (ECD), was used for measurement of $\mathrm{N}_{2} \mathrm{O}$ concentrations. High-purity $\mathrm{N}_{2}(99.999 \%)$ was used as carrier gas and the flow rate was maintained at $\sim 20.0 \mathrm{~mL} \mathrm{~min}^{-1}$. The column and the detector temperatures were set at 60 and $330{ }^{\circ} \mathrm{C}$, respectively. The volume of injection was $1 \mathrm{~mL}$. The standard $\mathrm{N}_{2} \mathrm{O}$ gas was supplied by the National Research Center for CRM's.

\subsection{Calculations and statistics}

Fluxes of $\mathrm{N}_{2} \mathrm{O}$ were calculated from the linear increase of gas concentrations in the chamber as a function of time (Nykänen et al., 1995). Statistical analyses were performed using SPSS 12.0 for Windows. The non-parametric Kendall's $W$ and Wilcox tests were used to establish the intrinsic difference from the experimental treatments for the two soils and the effect of application of REE fertilizers on $\mathrm{N}_{2} \mathrm{O}$ emission fluxes. Least significant difference (LSD) tests were used for the comparison of daily $\mathrm{N}_{2} \mathrm{O}$ fluxes among treatments during the two successive fertilizations.

\section{Results}

The results of pre-treatment tests are presented in Fig. 1. There were no statistically significant differences in the five replicates for both paddy soil and dryland soil (Kendall's $W$ test: $p_{\text {(paddy soil) }}=$ $\left.0.866 ; p_{\text {(dryland soil })}=0.425\right)$. Therefore the intrinsic difference in $\mathrm{N}_{2} \mathrm{O}$ flux emissions from different experimental pots could be neglected.

Fig. 2 shows the emission fluxes of $\mathrm{N}_{2} \mathrm{O}$ in the treatments (see Table 3). The fluxes of $\mathrm{N}_{2} \mathrm{O}$ in the treatment of only REE fertilizers application always remained at a low level during the two successive fertilizations. No significant differences were found between the treatment of the REE fertilizers application only and the control for the two soils, even when applying the 10-fold REE fertilizers

Table 3

Experimental treatments

\begin{tabular}{llllll}
\hline Soil & Treatments & & & \\
\cline { 2 - 6 } & $\mathrm{A}$ (control) & $\mathrm{B}^{\mathrm{a}}$ & $\mathrm{C}$ & $\mathrm{D}$ & $\mathrm{E}$ \\
\hline Paddy soil & $0 \mathrm{mg}_{\mathrm{RE}} \mathrm{kg}^{-1}$ & $0.6 \mathrm{mg}_{\mathrm{RE}} \mathrm{kg}^{-1}$ & $0.15 \mathrm{~g}_{\text {urea }} \mathrm{kg}^{-1}$ & $0.6 \mathrm{mg}_{\mathrm{RE}} \mathrm{kg}^{-1}$ & $6.0 \mathrm{mg}_{\mathrm{RE}} \mathrm{kg}^{-1}$ \\
& $0 \mathrm{~g}_{\mathrm{urea}} \mathrm{kg}^{-1}$ & $\left(6.0 \mathrm{mg}_{\mathrm{RE}} \mathrm{kg}^{-1}\right)$ & & $0.15 \mathrm{~g}_{\text {urea }} \mathrm{kg}^{-1}$ & $0.15 \mathrm{~g}_{\text {urea }} \mathrm{kg}^{-1}$ \\
Dryland soil & $0 \mathrm{mg}_{\mathrm{RE}} \mathrm{kg}^{-1}$ & $0.6 \mathrm{mg}_{\mathrm{RE}} \mathrm{kg}^{-1}$ & $0.15 \mathrm{~g}_{\text {urea }} \mathrm{kg}^{-1}$ & $0.6 \mathrm{mg}_{\mathrm{RE}} \mathrm{kg}^{-1}$ & $6.0 \mathrm{mg}_{\mathrm{RE}} \mathrm{kg}^{-1}$ \\
& $0 \mathrm{~g}_{\text {urea }} \mathrm{kg}^{-1}$ & $\left(6.0 \mathrm{mg}_{\mathrm{RE}} \mathrm{kg}^{-1}\right)$ & & $0.15 \mathrm{~g}_{\text {urea }} \mathrm{kg}^{-1}$ & $0.15 \mathrm{~g}_{\text {urea }} \mathrm{kg}^{-1}$ \\
\hline
\end{tabular}

${ }^{\mathrm{a}} 0.6 \mathrm{mg}_{\mathrm{RE}} \mathrm{kg}^{-1}$ for the first fertilization and $6 \mathrm{mg}_{\mathrm{RE}} \mathrm{kg}^{-1}$ for the second fertilization. 
(Wilcox test: $\quad p_{\text {(paddy soil) }}=0.29$ (control, $0.6 \mathrm{mg}_{\mathrm{RE}} \mathrm{kg}^{-1}$ ) and $\quad 0.11_{\left(\text {control, } 6.0 \mathrm{mg}_{\mathrm{RE}} \mathrm{kg}^{-1}\right)}$ and $p_{(\text {dryland soil })}=$ $0.33_{\text {(control, } 0.6 \mathrm{mg}_{\mathrm{RE}} \mathrm{kg}^{-1} \text { ) }}$ and $0.73_{\text {(control, } 6.0 \mathrm{mg}_{\mathrm{RE}} \mathrm{kg}^{-1} \text { ) }}$.

The peaks of $\mathrm{N}_{2} \mathrm{O}$ fluxes (Fig. 3) were the results of fertilizing urea and the urea plus REE fertilizers for paddy soil (A) and dryland soil (B). The peaks of

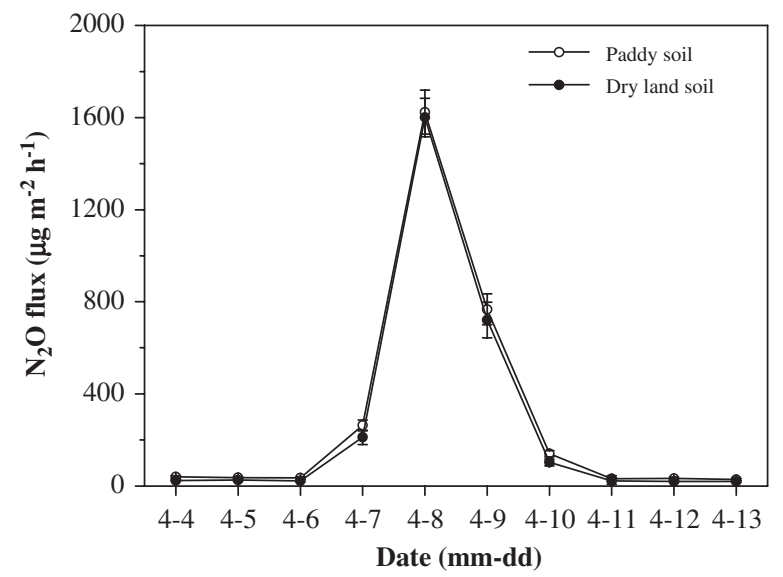

Fig. 1. $\mathrm{N}_{2} \mathrm{O}$ emission (mean $\left.\pm 1 \mathrm{SD}\right)$ in the pre-treatment $(3 \mathrm{~g}$ urea application).
$\mathrm{N}_{2} \mathrm{O}$ fluxes in the treatment of urea fertilization showed that the application of nitrogenous fertilizer clearly increased $\mathrm{N}_{2} \mathrm{O}$ emission from agricultural soils. This is entirely consistent with results from previously reported field studies (Iserman, 1994; Harrison et al., 1995). However, the peaks of $\mathrm{N}_{2} \mathrm{O}$ fluxes in the treatments of applying urea plus REE fertilizers were much higher than those from the urea only application, especially for the 10-fold REE fertilizers treatment.

From Fig. 3 it can be seen that total emission of $\mathrm{N}_{2} \mathrm{O}$ in the treatments of applying urea plus REE fertilizers were always higher than those of applying only urea and increased with the rise of REE fertilizers dosage in both paddy and dryland soils. The percentage increases were $21 \%$ and $19 \%$ for low dosage REE fertilizers treatment $\left(0.6 \mathrm{mg}_{\mathrm{RE}} \mathrm{kg}^{-1}+0.15 \mathrm{~g}_{\text {urea }} \mathrm{kg}^{-1}\right)$ and $104 \%$ and $60 \%$ for the 10-fold REE fertilizers treatment $\left(6.0 \mathrm{mg}_{\mathrm{RE}} \mathrm{kg}^{-1}+0.15 \mathrm{~g}_{\text {urea }} \mathrm{kg}^{-1}\right)$ for paddy soil and dryland soil, respectively. LSD tests were used for comparison of daily $\mathrm{N}_{2} \mathrm{O}$ fluxes among treatments during the two successive fertilizations. Significant differences were found among all treatments at
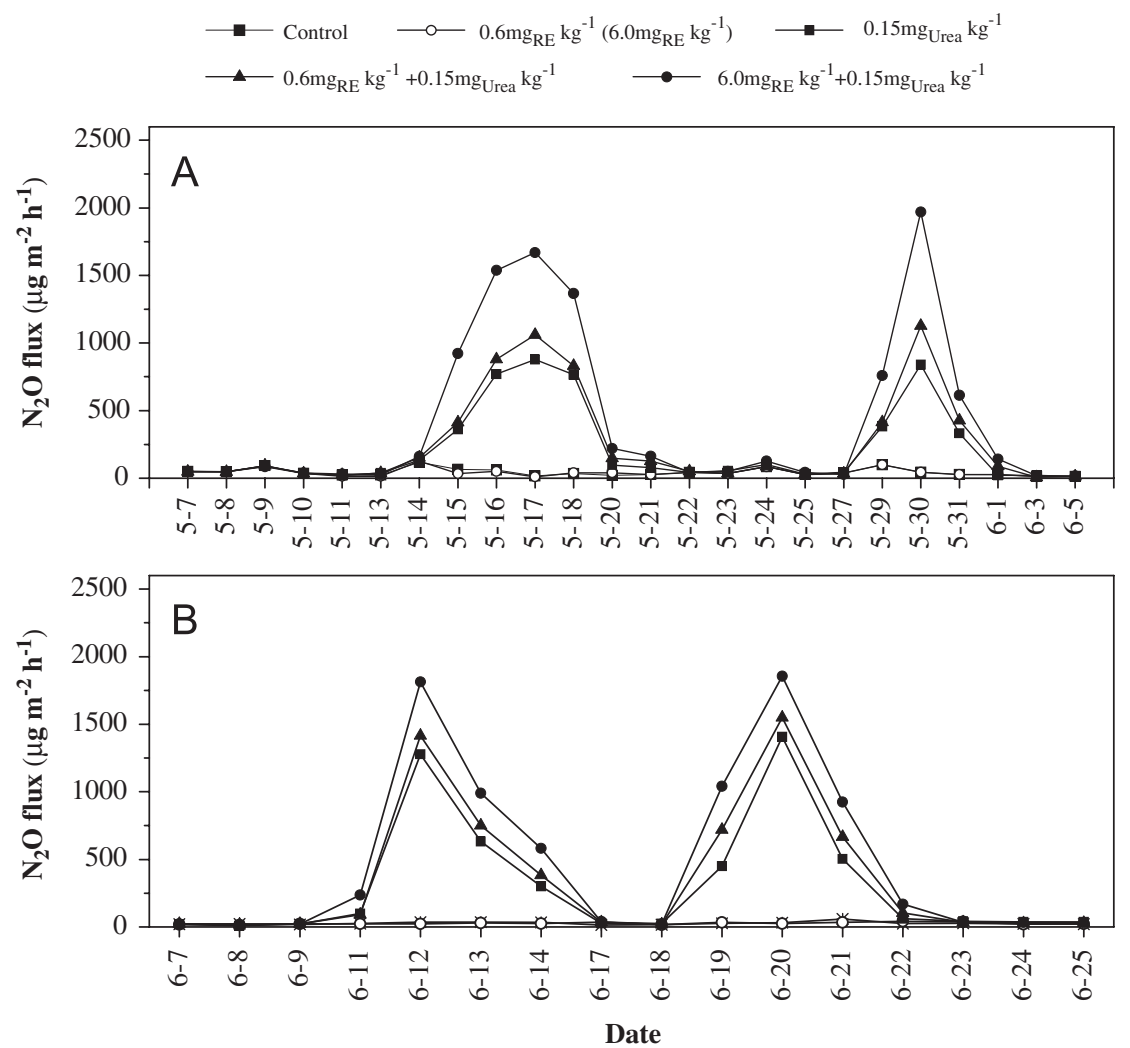

Fig. 2. $\mathrm{N}_{2} \mathrm{O}$ emission flux from paddy soil (A) and dryland soil (B) before and after two successive fertilizations. 


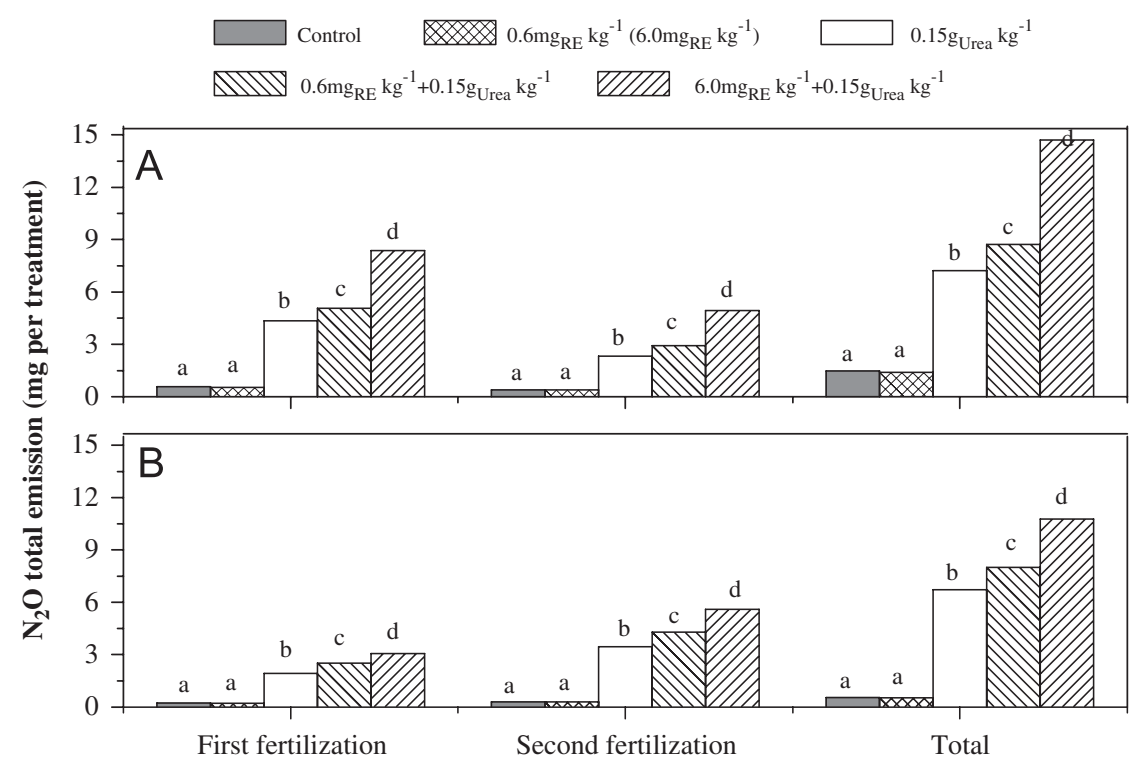

Fig. 3. Total emissions of $\mathrm{N}_{2} \mathrm{O}$ from paddy soil (A) and dryland soil (B) during two successive fertilizations (letters represent results of LSD tests for daily $\mathrm{N}_{2} \mathrm{O}$ fluxes among different treatments).

$p<0.05$ except for the difference at between the treatment of the REE fertilizers only application and the control for both paddy and dryland soils (Fig. 3).

\section{Discussion}

The results from this study indicated that the effect of applying the REE only fertilizer was not obtrusive in $\mathrm{N}_{2} \mathrm{O}$ emissions from the two soils. However, the fluxes of $\mathrm{N}_{2} \mathrm{O}$ in the treatments of the urea plus REE fertilizers application were much higher than those in the urea only application and significantly increased with an increase in the REE fertilizers dosage. $\mathrm{N}_{2} \mathrm{O}$ emissions from soils are the major consequences of biological nitrification and de-nitrification (Groffman, 1991; Conrad, 1996). $\mathrm{NH}_{4}^{+}-\mathrm{N}$ is the essential substance of nitrification and de-nitrification. $\mathrm{Xu}$ et al. (2001) reported that rare earth significantly affected the hydrolysis of urea and its hydrolyzed production in soil. The concentration of urea-derived exchangeable $\mathrm{NH}_{4}^{+}-\mathrm{N}$ in the soil significantly increased and appeared to be dose dependent when the dosage of applied REE fertilizers was more than $10 \mathrm{mg} \mathrm{kg}^{-1} \mathrm{dw}$ (dry weight). Bremner et al. (1981) observed that $\mathrm{N}_{2} \mathrm{O}$ fluxes from well-aerated soils were clearly correlated with $\mathrm{NH}_{4}^{+}$concentrations but not with $\mathrm{NO}_{3}^{-}$concentrations. In our study the $\mathrm{NH}_{4}^{+}-\mathrm{N}$ available for nitrification from urea hydro- lysis may have been increased due to the application of urea plus REE fertilizers.

On the other hand, Chu et al. (2000a, 2001) reported that the exterior REE lanthanum stimulated the microbial biomass nitrogen and respiration at low concentrations in red soil. As well, the processes of nitrification and de-nitrification are controlled by specific enzymes in soils. Studies showed that exogenous rare earth stimulates enzyme activity in soils (Liu and Wang, 2001; Xu et al., 2001; Chu et al., 2000b). REEs may serve as coenzymes for catalysis in soils (Ozaki et al., 2006). Hence, we may conclude from our study that bacteria and enzymes for nitrification and denitrification processes may be stimulated with the application of urea plus REE fertilizers. In addition, Zhu et al. (2002) evaluated the effect of lanthanum on nitrification in three Chinese soils by an incubation experiment and showed that the stimulation rate of soil nitrification reached about $20 \%$ in a red soil and $14 \%$ in a fluvo-aquatic soil at low concentrations of lanthanum. This is consistent with the percentage increase of total emissions of $\mathrm{N}_{2} \mathrm{O}$ from the urea plus low dosage REE fertilizers application in our study.

It is estimated that the area of REE fertilizers application accounts for about $5 \%$ of the total agricultural land in China (Liu, 2007). In fact, compound fertilizers such as urea, and carbon ammonium compounds, mixed with rare earth are, 
at present, the main part of rare-earth application in agriculture. In recent years, agricultural use of REE fertilizers has become widely extended in countries such as Korea, Japan and Australia. Therefore, it is important to take this wide application of REE fertilizers on greenhouse effects into account.

\section{Conclusions}

From our experiment we may conclude that the application of REE fertilizers can increase the emission of $\mathrm{N}_{2} \mathrm{O}$ from the soils fertilized by urea in northern China. This result indicates that the environmental consequences of the addition of rare earth to fertilizers should be of far reaching concern given the wide use of rare-earth fertilizers in agricultural activities in China. Our results also imply that the use of rare-earth fertilizers could lead to an increase of $\mathrm{NH}_{4}^{+}-\mathrm{N}$ available from urea hydrolysis and activate bacteria and enzymes in nitrification and de-nitrification.

\section{Acknowledgment}

This work was funded by the National Basic Research Program of China, No. 2005CB422206.

\section{References}

Battle, M., Bender, M., Sowers, T., Tans, P., Butler, J., Elkins, J., Ellis, J., Conway, T., Zhang, N., Lang, P., Clarke, A., 1996. Atmospheric gas concentrations over the past century measured in air from firn at the South pole. Nature 383, 231-235.

Bouwman, A., 1990. Exchange of greenhouse gases between terrestrial ecosystems and the atmosphere. In: Bouwman, A. (Ed.), Soil and the Greenhouse Effect. Wiley, Chichester, NY, pp. 61-127.

Bremner, J., Breitenbeck, G., Blackmer, A., 1981. Effect of anhydrous ammonia fertilization on emission of nitrous oxide from soils. Journal of Environment Quality 10, 77-80.

Brown, P., Rathjen, A., Graham, R., Tribe, D., 1990. Rare earth elements in biological systems. In: Gschneidner, Jr., K.A., Eyring, L. (Eds.), Handbook on the Physics and Chemistry of Rare Earths, vol. 13. Elsevier, Amsterdam, pp. 423-452.

Chu, H., Li, Z., Xie, Z., 2000a. Effect of lanthanum on the microflora of Red Soil. Environmental Science 6, 28-31 (in Chinese).

Chu, H., Zhu, J., Xie, Z., Li, Z., 2000b. Effect of lanthanum on urea and acid phosphates activities in Red Soil. Agricultural Environmental Protection 19, 193-195 (in Chinese).

Chu, H., Zhu, J., Xie, Z., Li, Z., Cao, Z., Zeng, Q., 2001. Effects of lanthanum on nitrification, phosphorus transformation and phenol decomposition in Red Soil. Journal of Chinese Rare Earth Society 19, 366-369 (in Chinese).
Conrad, R., 1996. Soil microorganisms as controllers of atmospheric trace gases $\left(\mathrm{H}_{2}, \mathrm{CO}, \mathrm{CH}_{4}, \mathrm{OCS}, \mathrm{N}_{2} \mathrm{O}\right.$ and $\left.\mathrm{NO}\right)$. Microbiology Review 60, 609-640.

Crutzen, P., 1970. The influence of nitrogen oxides on the atmospheric ozone content. Quarterly Journal of the Royal Meteorological Society 96, 320-325.

FAO and IAEA, 1992. Measurement of Methane and Nitrous Oxide Emissions from Agriculture. A Joint Undertaking by the Food and Agriculture Organization of the United Nations and the International Atomic Energy Agency. International Atomic Energy Agency, Vienna, pp. 5-6.

Groffman, P., 1991. Ecology of nitrification and de-nitrification in soil evaluated at scales relevant to atmospheric chemistry. In: Rogers, J.E., Whitman, W.B. (Eds.), Microbial Production and Consumption of Greenhouse Gases: Methane, Nitrogen Oxides and Halomethanes. American Society for Microbiology, Washington, DC, pp. 201-217.

Guo, B., 1998. Rare Earths in Agriculture. Chinese Agricultural Technology Press (in Chinese).

Harrison, R., Yamulki, S., Goulding, K., 1995. Effect of fertilizer application on $\mathrm{NO}$ and $\mathrm{N}_{2} \mathrm{O}$ fluxes from agriculture fields. Journal of Geophysical Research 100, 25923-25931.

Huo, M., Xiao, J., 1998. Theoretical and Applied Researches on Rare earths in China [M]. Higher Education Press (in Chinese).

Iserman, K., 1994. Agricultures share in the emission of trace gases affecting the climate and some cause oriented proposal for reducing this share. Environmental Pollution 83, 95-111.

Kim, H., 1995. Soil Sampling, Preparation and Analysis. Marcel Dekker, New York, pp. 40-260.

Liu, D., Wang, Z., 2001. Influence of rare earth elements on chemical transformation of nitrogen in agriculture soil. Journal of Applied Ecology 12, 545-548.

Liu, Y., 2007. Present state and main task of development of rare earth industry in China. Journal of Chinese Rare Earth Society 25, 257-263 (in Chinese).

Nykänen, H., Alm, J., Lång, K., Silvola, J., Martikainen, P., 1995. Emissions of $\mathrm{CH}_{4}, \mathrm{~N}_{2} \mathrm{O}$ and $\mathrm{CO}_{2}$ from a virgin fen and a fen drained for grassland in Finland. Journal of Biogeography 22, 1149-1155.

Ozaki, T., Suzuki, Y., Nankawa, T., Yoshida, T., 2006. Interactions of rare earth elements with bacteria and organic ligands. Journal of Alloys and Compounds 408-412, 1334-1338.

Pang, C., 1994. Manual of Fertilization. Guangxi Science and Technology Press (in Chinese).

Peng, A., Wang, Z., 1995. Recent research progress on environmental chemistry of rare-earth elements. Advanced Environmental Science 3, 22-30 (in Chinese).

Wang, W., Sze, N., 1980. Coupled effects of atmospheric $\mathrm{N}_{2} \mathrm{O}$ and $\mathrm{O}_{3}$ on the earth's climate. Nature 286, 589-590.

Xu, X., Wang, Z., 2001. Effect of lanthanum and mixtures of rare earths on ammonium oxidation and mineralization of nitrogen in soil. Journal of European Soil Science 52, 323-330.

Xu, X., Wang, Z., Liu, Y., 2001. Influence of rare earths on the hydrolysis of urea and its hydrolyzed product in soil. Journal of Applied Ecology 12, 739-742 (in Chinese).

Zhu, J., Chu, H., Xie, Z., Yagi, K., 2002. Effects of lanthanum on nitrification and ammonification in three Chinese soils. Nutrient Cycling in Agroecosystems 63, 309-314. 